\title{
Indirect Iodination on the Vinyl Double Bond of Andrographolide
}

\author{
Jutti Levita
}

Faculty of Pharmacy, Universitas Padjadjaran

J1. Raya Bandung-Sumedang Km.21, Jatinangor, Sumedang, West Java, Indonesia

Tel: 62-81-5604-3663 E-mail: la_via63@yahoo.com

\author{
Ni Made Widiastuti \\ Department of Pharmacy, Faculty of Mathematics and Natural Sciences \\ Universitas Udayana, Bukit Jimbaran, Bali \\ E-mail: weedy.aya.05@gmail.com
}

Ilma Nugrahani

School of Pharmacy, Institut Teknologi Bandung, Jl. Ganesha 10 Bandung 40116

West Java, Indonesia

E-mail: ilma_nugrahani@fa.itb.ac.id

Amir Musadad

School of Pharmacy, Institut Teknologi Bandung, Jl. Ganesha 10 Bandung 40116

West Java, Indonesia

E-mail: amir@fa.itb.ac.id

As'ari Nawawi

School of Pharmacy, Institut Teknologi Bandung, Jl. Ganesha 10 Bandung 40116

West Java, Indonesia

E-mail: asarinawawi@yahoo.com

Abdul Mutalib

Center of Radioisotope and Radiopharmaca, National Nuclear Agency

Serpong, Indonesia

E-mail: mutalib@batan.go.id

Slamet Ibrahim

School of Pharmacy, Institut Teknologi Bandung, Jl. Ganesha 10 Bandung 40116,

West Java, Indonesia

E-mail: sibrahim@fa.itb.ac.id

Received: September 5, 2011

Accepted: September 28, 2011

Published: December 1, 2011

doi:10.5539/ijc.v3n4p47

URL: http://dx.doi.org/10.5539/ijc.v3n4p47 


\begin{abstract}
Andrographolide is a bicyclic diterpenoid constituent of Andrographis paniculata which is used extensively in the traditional medicine in Indonesia to treat inflammations. The structure of andrographolide contains an $\alpha$-alkylidene $\gamma$-butyrolactone moiety, two olefin bonds at C-8(C-17) and C-12(C-13), and three hydroxyls at C-3, C-19 and C-14. Andrographolide's structure lacks of aromatic ring, hence the iodination reaction of this compound is quite an interesting challenge to be investigated. Iodine atom was incorporated at vinyl position by indirect reaction. The reaction was divided into two steps, which was started by a bromination in non polar medium, then followed by iodination. It is shown that the principal reaction is the addition of bromine atom to an $s p^{2}$ carbon atom of the vinyl group via electrophilic substitution. Bromination was carried out in chloroform solvent at room temperature to produce bromo-andrographolide. The iodination was applied further by using palladium triphenylphosphine catalyst. Positive charge iodine species was produced in situ with the addition of chloramine-T, an oxidizing agent, at $40{ }^{\circ} \mathrm{C}$. ${ }^{1} \mathrm{H}-\mathrm{NMR}$ study shows that iodine attacked the $\mathrm{C}-12(\mathrm{C}-13)$ vinyl bond which was confirmed by (1) the disappearance of proton chemical shift of C-12 at $\delta_{\mathrm{H}} 6.86 \mathrm{ppm}$ and (2) the change of proton chemical shifts of $\mathrm{C}-11$ which shifted downfield at $\delta_{\mathrm{H}} 2.74 \mathrm{ppm}$ and $2.63 \mathrm{ppm}$, due to the deshielding effect of iodine.
\end{abstract}

Keywords: Andrographolide, Iodination, Vinyl double bond, Electrophilic substitution

\title{
1. Introduction
}

The main reactions of halogenation with iodine belong either to nucleophilic or electrophilic substitutions. Direct iodination (replacement of hydrogen atom by a iodine atom) represents an exception almost for electrophilic substitution in arenes. Electrophilic iodination is a process in which formally a positively charged iodine attacks a system with high electron density such as an aromatic ring or a double bond. As a result a covalent carbon-iodine bond is formed with loss of a positively charged leaving group. The leaving group (the electrofuge) must necessarily depart without its electron pair. The most important leaving groups are those that can best exist without the pair of electrons necessary to fill the outer shell, i.e. the weakest Lewis acids. The most common leaving group is the proton (Eersels et al., 2005). When bromine is used as a leaving group for iodination, the advantage of such an iodine-for-bromine exchange (non-isotopic exchange) reaction is that a very high specific activity can be obtained, provided the radioiodinated compound is efficiently separated from its brominated precursor (Coenen et al., 2006).

Generally, halogenation is preferably carried out to aromatic moieties, but sometimes it has to be applied on a double bond. In recent years, Verbeek and his co-workers committed that they were the first to apply iodination reaction successfully on vinyl double bond of tiagabine molecule. In principal, tiagabine might be labelled in one of the thiophene moieties. However, to circumvent Z,E formation they decided to label the vinylic part (Figure 1). On the first step Verbeek directly brominated tiagabine in carbon tetrachloride medium to the vinyl double bond, to produce bromotiagabine in $70 \%$ yield. This reaction was followed by iodination to substitute the bromine by using $\mathrm{Na}-\mathrm{I}^{123}$ to form iodotiagabine by using the $\mathrm{Cu}(\mathrm{I})$ mediated non-isotopical exchange reaction generating the $\mathrm{Cu}(\mathrm{I})$ in situ with gentisic acid as the catalyst. The overall radiochemical yield after preparative HPLC (Rt $\mathbf{2}=42 \mathrm{~min}$., Rt $3=48 \mathrm{~min}$.) was 50\%, with a radiochemical purity of $>99 \%$. (Verbeek et al., 2007).

Andrographolide, a bioactive compound of sambiloto (Andrographis paniculata (Burm.F) Nees), is the major labdane diterpenoidal constituent in this plant. It has been used traditionally in the South East Asia countries, India, and China to treat various diseases. Andrographolide, a very bitter compound, was isolated in its pure form and characterized for the first time by Gorter at 1911. The structure of andrographolide has been analyzed by X-ray crystallographic method and given its systematic name: 3-[2-[decahydro-6-hydroxy-5-(hydroxymethyl) -5,8a-dimethyl-2-methylene-1-naphthalenyl] ethylidine]dihydro-4-hydroxy-2(3H)-furanone (Smith et al., 1982). This compound has many bioactivities including anti-inflammatory via different mechanisms (Chiou et al., 2000; Shen et al., 2002; Satyanarayana et al., 2004; Wang et al., 2004; Xia et al., 2004; Hidalgo et al., 2005; Sheeja et al., 2006; Abu-Ghefreh et al., 2009; Bao et al., 2009; Li, 2009; Suebsasana, 2009; Chandrasekaran et al., 2010; Chao et al., 2010; Levita et al., 2010), anticancer and antitumour (Rajagopal et al., 2003; Satyanarayana et al., 2004; Shen et al., 2009; Varma et al., 2009; Lee et al., 2010; Tan et al., 2010; Zhou et al., 2010), hepatoprotective against various inducers (Handa \& Sharma, 1990; Visen et al., 1993), immunomodulator (Wang et al., 2010), antioxidant (Sheeja et al., 2006; Akowuah et al., 2008; Lin et al., 2009), antidiabetic (Zhang et al., 2009), antimicrobe (Xu et al., 2006), and antivirus (Calabrese et al., 2000; Chen et al., 2009).

Andrographolide (Figure 2) has an $\alpha$-alkylidene $\gamma$-butyrolactone, two olefin bonds at C-8 and C-12, and three hydroxyls at C-3, C-19 and C-14 (Nanduri et al., 2004). Its molecular formula is $\mathrm{C}_{20} \mathrm{H}_{30} \mathrm{O}_{5}$. Andrographolide is soluble in methanol, ethanol, pyridine, acetic acid and acetone, but it is slightly dissolved in ether and water. Its 
melting point is $228-230{ }^{\circ} \mathrm{C}$ and its ultraviolet $\lambda \max$ in ethanol is $223 \mathrm{~nm}$. Andrographolide's structure lacks of aromatic ring, hence the iodination reaction of this compound is quite an interesting challenge to be investigated. Iodine atom was incorporated at vinyl position by indirect reaction via electrophilic substitution. Electrophilic substitution was chosen due to the instability of andrographolide to high temperature as often needed in nucleophilic reaction. The reaction was divided into two steps, which was started by a bromination in non polar medium, and then followed by iodination. It is shown that the principal reaction is the addition of bromine atom to an $s p^{2}$ carbon atom of the vinyl group via electrophilic substitution. Bromination was carried out in chloroform solvent at room temperature to produce bromo-andrographolide. The iodination was applied further by using palladium triphenylphosphine catalyst.

\section{Materials and Methods}

\subsection{Chemicals}

Andrographolide 98\% $500 \mathrm{mg}$ CAS 5508-58-7 for R \& D use and palladium triphenylphosphine analytical grade were purchased from Aldrich. Prior to use the compound was dissolved in methanol and chloroform, respectively. Bromine liquid and chloroform analytical grade were purchased from E.Merck.

\subsection{Iodination}

Accurately weighed $\pm 35 \mathrm{mg}$ andrographolide $(0.1 \mathrm{mmol})$ was added by $0.15 \mathrm{ml}$ of bromine liquid in $\mathrm{CHCl}_{3}(1: 1$ $\mathrm{v} / \mathrm{v}$ ). The mixture was vortex-mixed (Maximix plus-Thermolyne) for 5 minutes at room temperature. The excess of bromine was evaporated, and added by $0.3 \mathrm{ml}$ of palladium triphenylphosphine in chloroform $(1 \mu \mathrm{mol})$. The solution was vortex-mixed for one minute and followed by the addition of $20 \mu \mathrm{l}$ of sodium iodide solution and $0.25 \mathrm{ml}$ of chloramine- $\mathrm{T}(1 \mathrm{mg} / \mathrm{ml}$ in sterilized distilled water). The solution was vortex-mixed for one minute and heated at $40{ }^{\circ} \mathrm{C}$ for 5 minutes. Oxidation was stopped by the addition of $0.25 \mathrm{ml}$ of sodium metabisulfite solution $(1 \mathrm{mg} / \mathrm{ml}$ in sterilized distilled water).

\subsection{Computational study}

Computational study was carried out to predict (1) the position of halogenations, and (2) the chemical shifts of protons in andrographolide and iodo-andrographolide structures. Softwares used in this step were ChemOffice 2004, ArgusLab (Mark A. Thompson Planaria Software LLC, Seattle, WA, http://www.arguslab.com), and HyperChem Professional 7.

\section{Results and Discussion}

\subsection{Computational study}

The main reactions of halogenation with iodine belong either to nucleophilic or electrophilic substitutions. Electrophilic iodination is a process in which positive charged iodine attacks a system with high electron density such as an aromatic ring or a double bond. ArgusLab software calculates and predicts the position of iodination based on the electron density (Figure 3).

HyperChem Professional 7.0 calculates that iodination on andrographolide increases its lypophylicity as showed by the increasing of the cLog P value (Table 1).

The addition of bromine molecule which was carried out in chloroform as a non polar medium, produced bromo-andrographolide, and then iodo-andrographolide was yielded from further iodination reaction catalyzed by palladium triphenylphosphine (Figure 4).

The structure of andrographolide and iodo-andrographolide were compared by the ${ }^{1} \mathrm{H}-\mathrm{NMR}$ spectra which showed that iodination was occurred at C-12 (Figure 5 and Table 2).

The two olefin bonds at C-12 and C-17 gave their chemical shifts at $\delta_{\mathrm{H}} 4.5-7.0 \mathrm{ppm}$ which were caused by the increasing of electronegativity of $s p^{2}$ Carbon and anisotropy of $\mathrm{C}=\mathrm{C}$ bond hence resulted in higher frequency (lower magnetic field) of the peaks. Proton at C-12 double bond, which located near a carbonyl, was strengthened by both the anisotropic effect of the carbonyl and conjugation, hence it occured in higher frequency at $\delta_{\mathrm{H}} 6.86 \mathrm{ppm}$. While proton at C-17 double bond occurred at $\delta_{\mathrm{H}} 4.89 \mathrm{ppm}$ and $4.67 \mathrm{ppm}$. Proton position of these two double bonds is very important to identify the position of halogenation.

${ }^{1} \mathrm{H}-\mathrm{NMR}$ study shows that iodine attacked the C-12(C-13) vinyl bond which was confirmed by the disappearance of proton chemical shift of $\mathrm{C}-12$ at $\delta_{\mathrm{H}} 6.86 \mathrm{ppm}$. The iodination position was further confirmed by studying the chemical shift of $\mathrm{H}-11$ which are in the neighbouring position with $\mathrm{H}-12$. The peaks of $\mathrm{H}-11$ show a downfield shift at $\delta_{\mathrm{H}} 2.74 \mathrm{ppm}$ and $2.63 \mathrm{ppm}$, probably due to the deshielding effect of iodine. Iodination was positively confirmed by these data. The result of ${ }^{1} \mathrm{H}-\mathrm{NMR}$ analysis was compared with computational study which was 
calculated by using ChemOffice software as showed in Figure 6. ChemOffice calculation showed estimation of proton chemical shift of andrographolide and 12-bromo-andrographolide. The chemical shift of H-12 $\left(\delta_{\mathrm{H}} 6.86\right.$ $\mathrm{ppm}$ ) which was available in andrographolide molecule (Figure $6 \mathrm{left}$ ) was not detected in bromo-andrographolide molecule (Figure 6 right). Bromine ion $\left(\mathrm{Br}^{+}\right)$preferred to attack $\mathrm{C}-12$ double bond instead of $\mathrm{C}-17$ because $\mathrm{C}-12$ which was located near a carbonyl had a higher electronegativity than $\mathrm{C}-17$.

\section{Conclusion}

Indirect iodination on the vinyl bond of andrographolide via electrophilic substitution had successfully produced iodo-andrographolide. Iodine was incorporated at $\mathrm{C}-12$ double bond as proven by ${ }^{1} \mathrm{H}-\mathrm{NMR}$ which showed the disappearance of proton chemical shift of $\mathrm{C}-12$ at $\delta_{\mathrm{H}} 6.86 \mathrm{ppm}$ and the change of proton chemical shifts of C-11 which shifted downfield at $\delta_{\mathrm{H}} 2.74 \mathrm{ppm}$ and $2.63 \mathrm{ppm}$, due to the deshielding effect of iodine.

\section{References}

Abu-Ghefreh, A. A., Canatan, H., \& Ezeamuzie, C.I. (2009). In vitro and in vivo anti-inflammatory effects of $\begin{array}{llll}\text { andrographolide. } & \text { International } & \text { Immunopharmacology, } & 9(3),\end{array}$ http://dx.doi.org/10.1016/j.intimp.2008.12.002

Akowuah, G.A., Zhari, I., \& Mariam, A. (2008). Analysis of urinary andrographolides and antioxidant status after oral administration of Andrographis paniculata leaf extract in rats. Food Chem. Toxicol., 46(12), 3616-3620. http://dx.doi.org/10.1016/j.fct.2008.09.008

ArgusLab, \& Mark A. Thompson Planaria Software LLC, Seattle, WA, http://www.arguslab.com.

Bao, Z., Guan, S., Cheng, C., Wu, S., Wong, S.H., Kemeny, D.M., Leung, B.P., \& Wong, W.S.F. (2009). A Novel Antiinflammatory Role for Andrographolide in Asthma via Inhibition of the Nuclear Factor-kappaB Pathway. Am. J. Respir. Crit. Care Med., 179, 657-665. http://dx.doi.org/10.1164/rccm.200809-1516OC

Calabrese, C., Berman, S.H., Babish, J.G., Ma, X., Shinto, L., Dorr, M., Wells, K., Wenner, C.A., \& Standish, L.J. (2000). A phase I trial of andrographolide in HIV positive patients and normal volunteers. Phytotherapy Research, 14 , 333-338. http://dx.doi.org/10.1002/1099-1573(200008)14:5\%3C333::AID-PTR584\%3E3.0.CO;2-D

Chandrasekaran, C.V., Gupta ${ }^{a}$, A., \& Agarwal, A. (2010). Effect of an extract of Andrographis paniculata leaves on inflammatory and allergic mediators in vitro. Journal of Etnopharmacology, article in press. http://dx.doi.org/10.1016/j.jep.2010.03.007

Chao, W.W., Kuo, Y.H., \& Lin, B.F. (2010). Anti-inflammatory activity of new compounds from Andrographis paniculata by NF-kappaB transactivation inhibition. J. Agric. Food Chem., 58(4), 2505-2512. http://dx.doi.org/10.1021/jf903629j

Chen, J.X., Xue, H.J., Ye, W.C., Fang, B.H., Liu, Y.H., Yuan, S.H., Yu, P., \& Wang, Y.Q. (2009). Activity of andrographolide and its derivatives against influenza virus in vivo and in vitro, Biol. Pharm. Bull., 32(8), 1385-1391. http://dx.doi.org/10.1248/bpb.32.1385

Chiou, W-F., Chen, C-F., \& Lin, J-J. (2000). Mechanisms of suppression of inducible nitric oxide synthase (iNOS) expression in RAW 264.7 cells by andrographolide, British Journal of Pharmacology, 129, 1553-1560. http://dx.doi.org/10.1038/sj.bjp.0703191

Coenen, H.H., Mertens, J., \& Maziere, B. (2006). Radioiodination Reactions for Radiopharmaceuticals, Compendium for Effective Synthesis Strategies, Springer, Dordrecht, The Netherlands. ISBN 1-4020-4561-1.

Dubois, J.E., Toullec, J., \& Fain D. (1973). Addition du brome sur l'allyl-4 anisole via un intermediaire phenonium. Tetrahedron Lett., 4859-4860. http://dx.doi.org/10.1016/S0040-4039(01)87356-1

Fujita, T., Fujitani, R., Takeda, Y., Takaishi, Y., Yamada, T., Kido, M., \& Miura, I. (1984). On the Diterpenoids of Andrographis paniculata: X-Ray Crystallographic Analysis of Andrographolide and Structure Determination of New Minor Diterpenoids. Chem. Pham. Bull., 32(6), 2117-2125.

Handa, S.S., \& Sharma, A. (1990). Hepatoprotective activity of andrographolide against galactosamine \& paracetamol intoxication in rats. Indian J. Med. Res., 92, 284-292.

Hidalgo, M.A., Romero, A., Figueroa, J., Cortes, P., Concha, I.I., Hancke, J.L., \& Burgos, R.A. (2005). Andrographolide interferes with binding of nuclear factor-kB to DNA in HL-60-derived neutrophilic cells. British Journal of Pharmacology, 144, 680-685. http://dx.doi.org/10.1038/sj.bjp.0706105 
Lee, Y-C., Lin, H-H., Hsu, C-H., Wang, C-J., Chiang, T-A., \& Chen, J-H. (2010). Inhibitory effects of andrographolide on migration and invasion in human non-small cell lung cancer A549 cells via down-regulation of PI3K/Akt signaling pathway. European Journal of Pharmacology, 632, 23-32. http://dx.doi.org/10.1016/j.ejphar.2010.01.009

Levita, J., Nawawi, A., Mutholib, A., \& Ibrahim, S. (2010). Andrographolide Inhibits COX-2 Expression in Human Fibroblast Cells Due to Its Interaction with Arginine and Histidine in Cyclooxygenase Site. J. Applied Sci., 10(14), 1481-1484. http://dx.doi.org/10.3923/jas.2010.1481.1484

Li, J., Luo, L., Wang, X., Liao, B., \& Li, G. (2009). Inhibition of NF-kappaB expression and allergen-induced airway inflammation in a mouse allergic asthma model by andrographolide. Cell Mol Immunol., 6(5), 381-385. http://dx.doi.org/10.1038/cmi.2009.49

Nanduri, S., Nyavanandi, V.K., Thunuguntla, S.S.R., Kasu, S., Pallerla, M.K., Ram, P.S., Rajagopal, S., Kumar, R.A., Ramanujam, R., Babu, J.M., Vyas, K., Devi, A.S., Reddy, G.O., \& Akella, V. (2004). Synthesis and structure-activity relationship of andrographolide analogues as cytotoxic agents. Bioorg. Med. Chem. Lett., 14, 4711-4717. http://dx.doi.org/10.1016/j.bmol.2004.06.090

Pincock, J.A., \& Somawardhana, C. (1978). The bromination of 3-arylpropynes: Evidence for phenyl participation at a vinyl cation. Can. J. Chem., 56, 1164-1169. http://dx.doi.org/10.1139/v78-195

Rajagopal, S., Kumar, R.A., Deevi, D.S., Satyanarayana, C., \& Rajagopalan, R. (2003). Andrographolide, a potential cancer therapeutic agent isolated from Andrographis paniculata. Journal of Experimental Therapeutics and Oncology, 3(3), 147-158. http://dx.doi.org/10.1046/j.1359-4117.2003.01090.x

Satyanarayana, C., Deevi, D. S., Rajagopalan, R., Srinivas, N., \& Rajagopal, S. (2004). DRF 3188 a novel semi-synthetic analog of andrographolide: cellular response to MCF7 breast cancer cells, BMC Cancer, 4(26), 1-8. http://www.biomedcentral.com/1471-2407/4/26

Sheeja, K., Shihab, P.K., \& Kuttan, G. (2006). Antioxidant and anti-inflammatory activities of the plant Andrographis paniculata Nees. Immunopharmacology and Immunotoxicology, 28, 129-140. http://dx.doi.org/10.1080/08923970600626007

Shen, Y-C., Chen, C-F., \& Chiou, W-F. (2002). Andrographolide prevents oxygen radical production by human neutrophils: possible mechanisms involved in its anti-inflammatory effect. British Journal of Pharmacology, 135, 399-406. http://dx.doi.org/10.1038/sj.bjp.0704493

Smith III, A.B., Toder, B.H., Carroll, P.J., \& Donohue, J. (1982). Andrographolide: an X-ray crystallographic analysis. Journal of Crystallographic and Spectroscopic Research, 12(4), 309-319. http://dx.doi.org/10.1007/BF01159047

Suebsasana S., Pongnaratorn P., Sattayasai J., Arkaravichien T., Tiamkao S., \& Aromdee C. (2009). Analgesic, antipyretic, anti-inflammatory and toxic effects of andrographolide derivatives in experimental animals. Arch. Pharm. Res., 32(9), 1191-1200. http://dx.doi.org/10.1007/s12272-009-1902-x

Tan, Y., Chiow, K.H., Huang, D., \& Wong, S.H. (2010). Andrographolide regulates epidermal growth factor receptor and transferrin receptor trafficking in epidermoid carcinoma (A-431) cells. British Journal of Pharmacology, 159(7), 1497-1510. http://dx.doi.org/10.1111/j.1476-5381.2009.00627.x

Varma, A., Padh, H., \& Shrivastava, N. (2009). Andrographolide: A New Plant-Derived Antineoplastic Entity on Horizon. Evidence-Based Complementary and Alternative Medicine, 1-9. http://dx.doi.org/10.1093/ecam/nep135

Verbeek, J., Schijns, O., Hoogland, G., Van Kroonenburgh, M., \& Herscheid, J.D.M. (2007). Synthesis of I-123 Labeled Tiagabine Analogue. A Potential Radioligand for GABA Transporter GAT-1. published as poster presentation at 17th International Symposium on Radiopharmaceutical Sciences, Aachen Germany.

Visen, P.K., Shukla, B., Patnaik, G.K., \& Dhawan, B.N. (1993). Andrographolide protects rat hepatocytes against paracetamol-induced damage. J. Ethnopharmacol., $40(2), \quad 131-136$. http://dx.doi.org/10.1016/0378-8741(93)90058-D

Wang, W., Wang, J., Dong, S.F., Liu, C.H., Italiani, P., Sun, S.H., Xu, J., Boraschi, D., Ma, S.P., \& Qu, D. (2010). Immunomodulatory activity of andrographolide on macrophage activation and specific antibody response. Acta Pharmacol Sin., 31(2), 191-201. http://dx.doi.org/10.1038/aps.2009.205

Xia, Y-F., Ye, B-Q., Li, Y-D., Wang, J-G., He, X-J., Lin, X., Yao, X., Ma, D., Slungaard., A., Hebbel., R.P., Key, N.S., \& Geng, J-G. (2004). Andrographolide attenuates inflammation by inhibition of NF-kB activation 
through covalent modification of reduced cysteine62 of p50. The Journal of Immunology, 4207-4217. http://www.jimmunol.org/cgi/content/full/173/6/4207.

Xu, Y., Marshall, R.L., \& Mukkur, T.K.S. (2006). An investigation on the antimicrobial activity of Andrographis paniculata extracts and andrographolide in vitro. Asian J. Plant Sci., 5, 527-530. http://dx.doi.org/10.3923/ajps.2006.527.530

Zhang, Z., Jiang, J., Yu, P., Zeng, X., Larrick, J.W., \& Wang, Y. (2009). Hypoglycemic and beta cell protective effects of andrographolide analogue for diabetes treatment. Journal of Translational Medicine, 7, 62. http://dx.doi.org/10.1186/1479-5876-7-62

Zhou, J., Ong, C.N., Hur, G.M., \& Shen, H.M. (2010). Inhibition of the JAK-STAT3 pathway by andrographolide enhances chemosensitivity of cancer cells to doxorubicin. Biochem Pharmacol., 79(9), 1242-1250. http://dx.doi.org/10.1016/j.bcp.2009.12.014

Table 1. Comparation of andrographolide and iodo-andrographolide

\begin{tabular}{|c|c|c|c|}
\hline Compound & cLog $\mathbf{P}$ & Volume & Mass \\
\hline Andrographolide & 2.24 & $963.29 \AA^{3}$ & $351.46 \mathrm{amu}$ \\
\hline Iodo-andrographolide & 2.74 & $1021.28 \AA^{3}$ & $476.35 \mathrm{amu}$ \\
\hline
\end{tabular}

Table 2. Chemical shift and proton position of andrographolide and iodo-andrographolide

\begin{tabular}{|c|c|c|c|c|c|}
\hline \multirow{2}{*}{$\begin{array}{l}\text { Proton } \\
\text { position }\end{array}$} & \multicolumn{3}{|c|}{$\begin{array}{l}\text { Chemical shift } \\
\delta(\mathrm{ppm})\end{array}$} & \multirow{2}{*}{$\begin{array}{l}\text { ChemDraw } \\
\text { Ultra prediction } \\
\text { for } \\
\text { andrographolide }\end{array}$} & \multirow[t]{2}{*}{$\begin{array}{l}\text { ChemDraw Ultra } \\
\text { prediction for } \\
\text { iodo-andrographolide }\end{array}$} \\
\hline & $\begin{array}{l}\text { Andrographolide } \\
\text { in } \mathrm{CD}_{3} \mathrm{OD}\end{array}$ & $\begin{array}{l}\text { Andrographolid } \\
\text { e in } \mathrm{CD}_{3} \mathrm{OD} \\
\text { (Medforth et } \\
\text { al., 1990) }\end{array}$ & $\begin{array}{c}\text { Iodo } \\
\text {-andrographolide }\end{array}$ & & \\
\hline $\mathrm{H}-\mathrm{1}_{\mathrm{ax}}$ & 1.30 & 1.30 & 1.31 & 1.24 & 1.24 \\
\hline $\mathrm{H}-1_{\mathrm{eq}}$ & 1.80 & 1.80 & 1.82 & 1.49 & 1.49 \\
\hline $\mathrm{H}-2_{\mathrm{ax}}$ & 1.82 & 1.80 & 1.99 & 1.72 & 1.72 \\
\hline $\mathrm{H}-2_{\mathrm{eq}}$ & 1.82 & 1.80 & 1.95 & 1.47 & 1.47 \\
\hline $\mathrm{H}-3$ & 3.41 & 3.41 & 3.44 & 3.15 & 3.15 \\
\hline $\mathrm{H}-5$ & 1.33 & 1.32 & 1.29 & 1.39 & 1.39 \\
\hline $\mathrm{H}-6_{\mathrm{ax}}$ & 1.39 & 1.36 & 1.45 & 1.16 & 1.16 \\
\hline $\mathrm{H}-6_{\mathrm{eq}}$ & 1.87 & 1.86 & 1.95 & 1.41 & 1.41 \\
\hline $\mathrm{H}-7_{\mathrm{ax}}$ & 2.03 & 2.04 & 2.18 & 2.01 & 2.01 \\
\hline $\mathrm{H}-7_{\mathrm{eq}}$ & 2.44 & 2.43 & 2.35 & 1.91 & 1.91 \\
\hline H-9 & 1.92 & 1.92 & 1.99 & 2.18 & 2.18 \\
\hline $\mathrm{H}-11_{\mathrm{a}}$ & 2.63 & 2.63 & 2.74 & 2.09 & 2.09 \\
\hline $\mathrm{H}-11_{\mathrm{b}}$ & 2.59 & 2.58 & 2.63 & 1.84 & 1.84 \\
\hline $\mathrm{H}-12$ & 6.85 & 6.85 & Not detected & 6.86 & None \\
\hline H-14 & 5.01 & 5.01 & 5.01 & 4.50 & 4.50 \\
\hline
\end{tabular}




\begin{tabular}{|c|c|c|c|c|c|}
\hline $\mathrm{H}-15_{\mathrm{a}}$ & 4.46 & 4.45 & 4.48 & 4.47 & 4.47 \\
\hline $\mathrm{H}-15_{\mathrm{b}}$ & 4.17 & 4.16 & 4.06 & 4.22 & 4.22 \\
\hline $\mathrm{Me}-16$ & 0.75 & 0.76 & 1.22 & 1.16 & 1.16 \\
\hline $\mathrm{H}-17_{\mathrm{a}}$ & 5.05 & 4.89 & 5.05 & 4.88 & 4.88 \\
\hline $\mathrm{H}-17_{\mathrm{b}}$ & 4.67 & 4.67 & 4.57 & 4.63 & 4.63 \\
\hline $\mathrm{He}-18$ & 1.22 & 1.22 & 1.23 & 1.16 & 1.16 \\
\hline $\mathrm{H}-19_{\mathrm{a}}$ & 4.13 & 4.12 & 3.98 & 3.58 & 3.58 \\
\hline $\mathrm{H}-19_{\mathrm{b}}$ & 3.38 & 3.37 & 3.32 & 3.33 & 3.33 \\
\hline
\end{tabular}

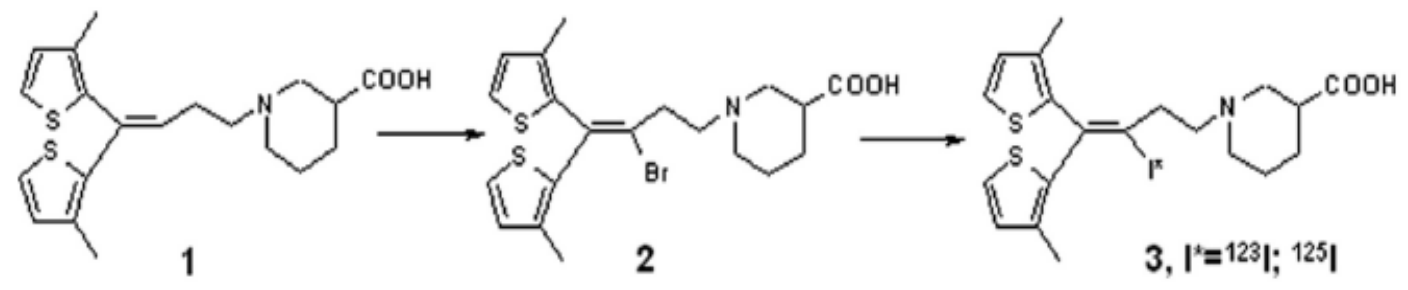

Figure 1. Vinyl bromination and iodination of tiagabine (Verbeek et al., 2007)

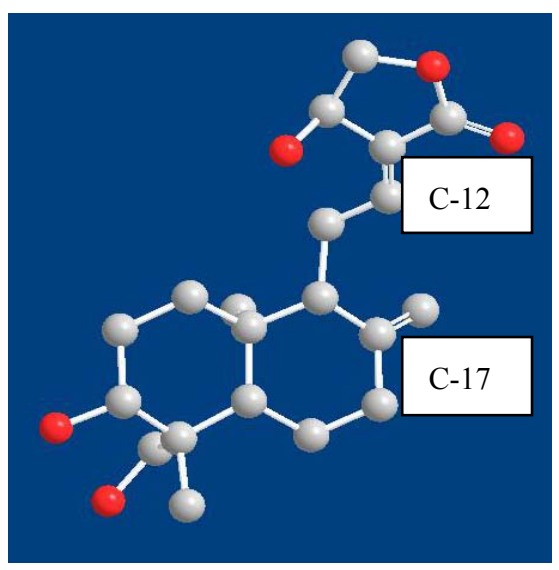

Figure 2. 3D structure of andrographolide

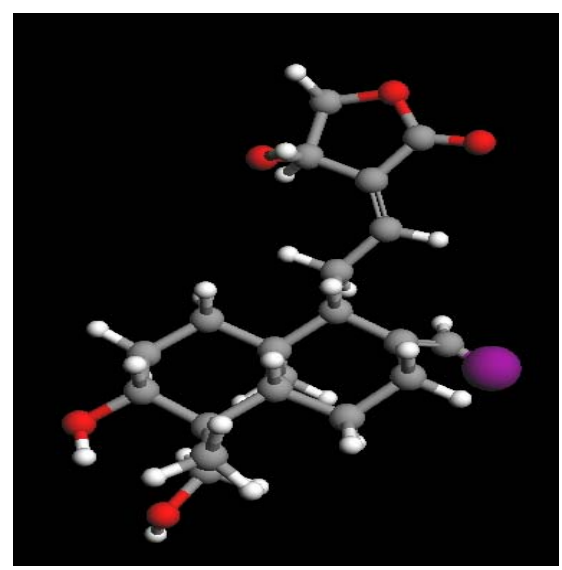

(a)

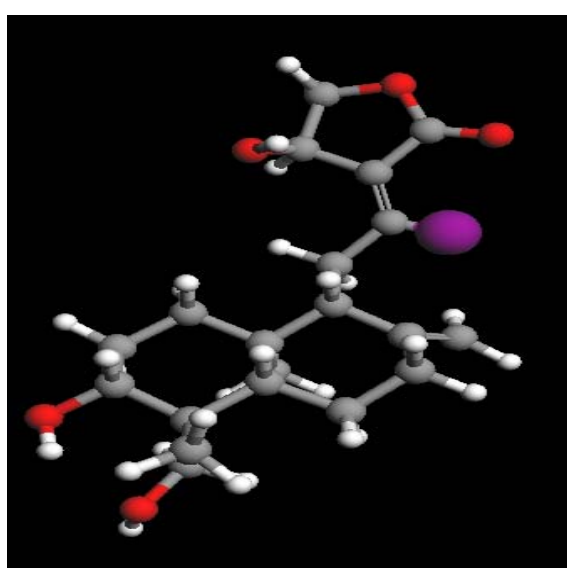

(b)

Figure 3. Prediction of iodination reaction on andrographolide molecule (a) At C-17; (b)At C-12

(Carbon atom is visualized in grey, red for oxygen, white for hydrogen, and violet for Iodine) 
First step:

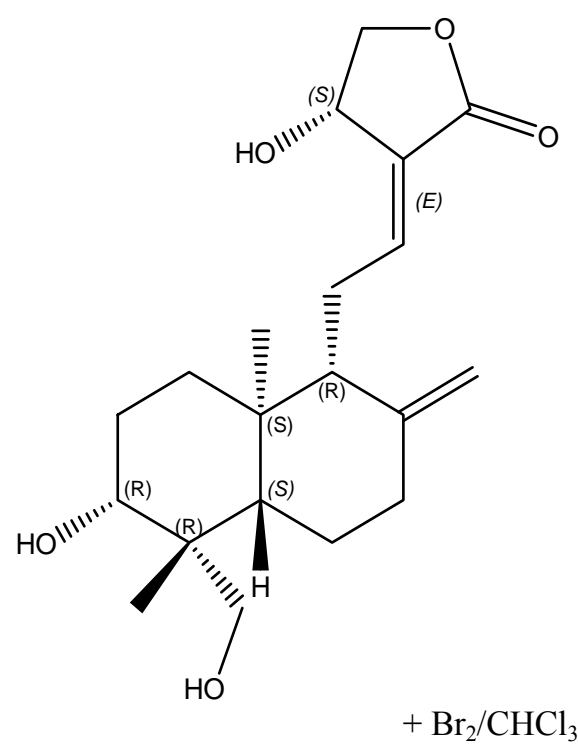

Andrographolide

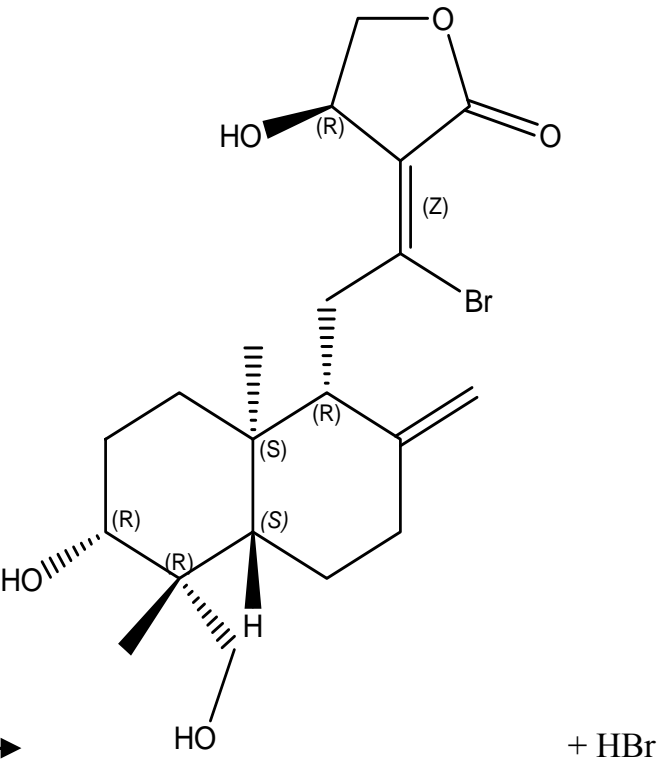

bromo-andrographolide

Second step:

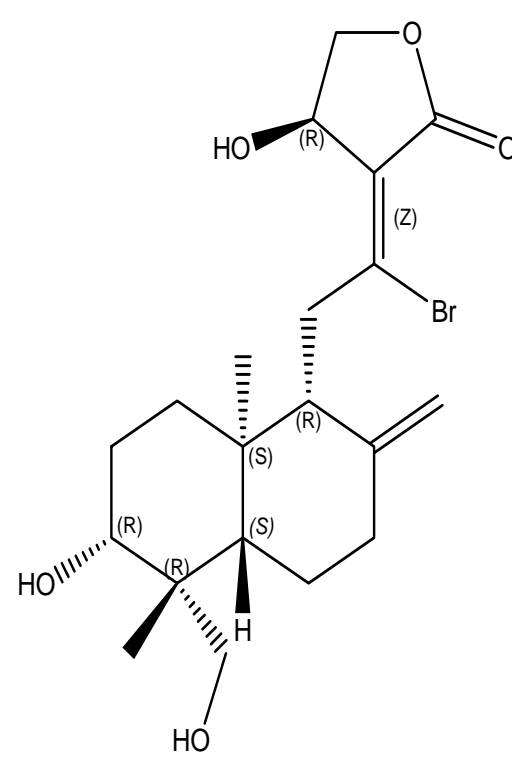

bromo-andrographolide
+ NaI chloramine-T/40 ${ }^{\circ} \mathrm{C}, 5$ minutes $\mathrm{Pd}(\mathrm{PPh})_{3} / \mathrm{CHCl}_{3}$

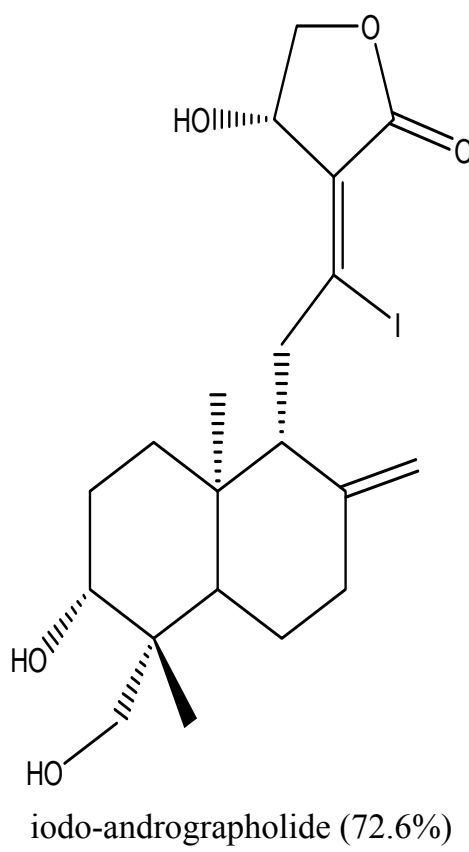

Figure 4. Proposed reaction of vinyl iodination of andrographolide 

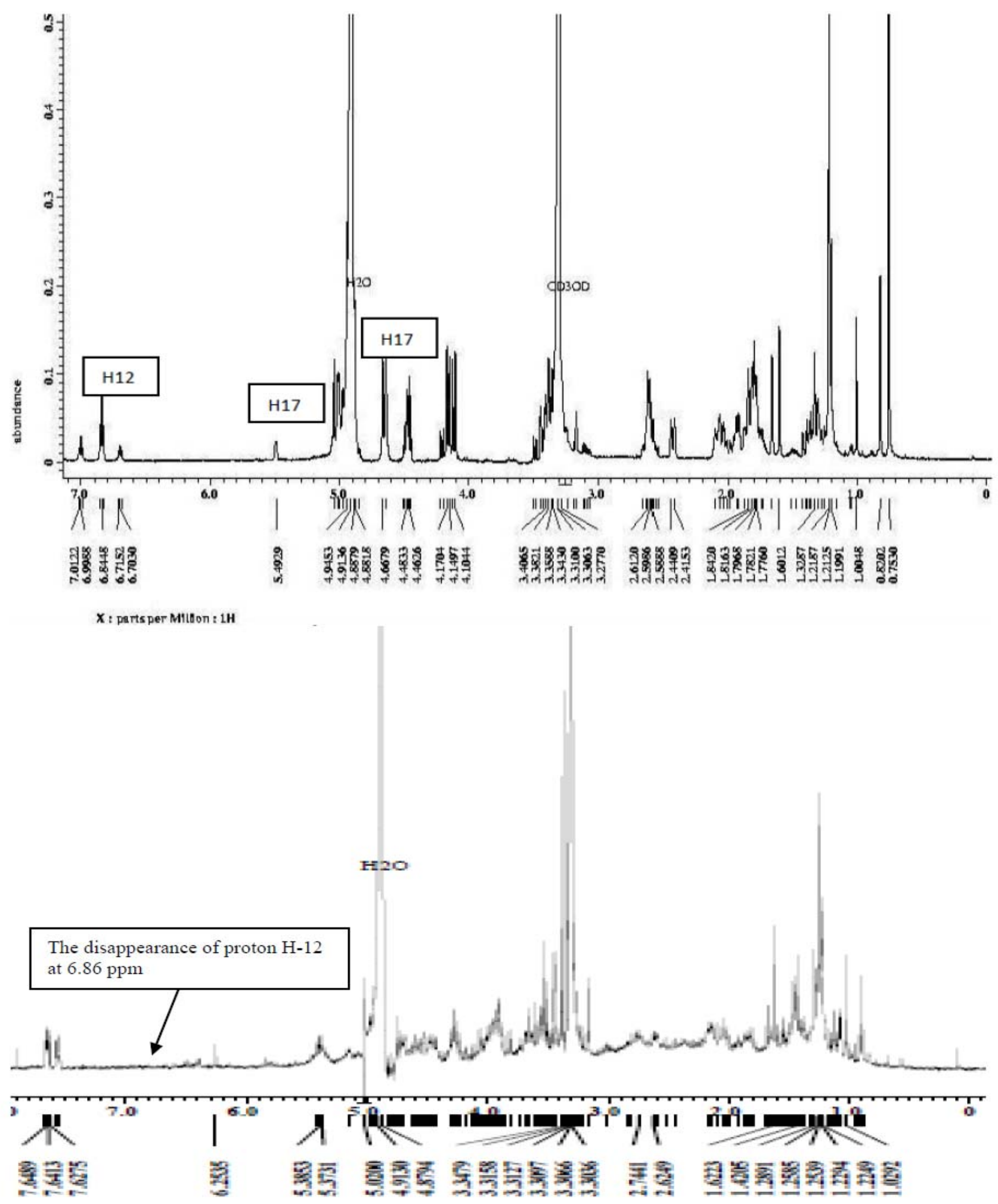

Figure 5. ${ }^{1} \mathrm{H}-\mathrm{NMR}$ spectrum of andrographolide (a) and iodo-andrographolide (b) 


\section{ChemNMR H-1 Estimation}

\section{ChemNMR H-1 Estimation}
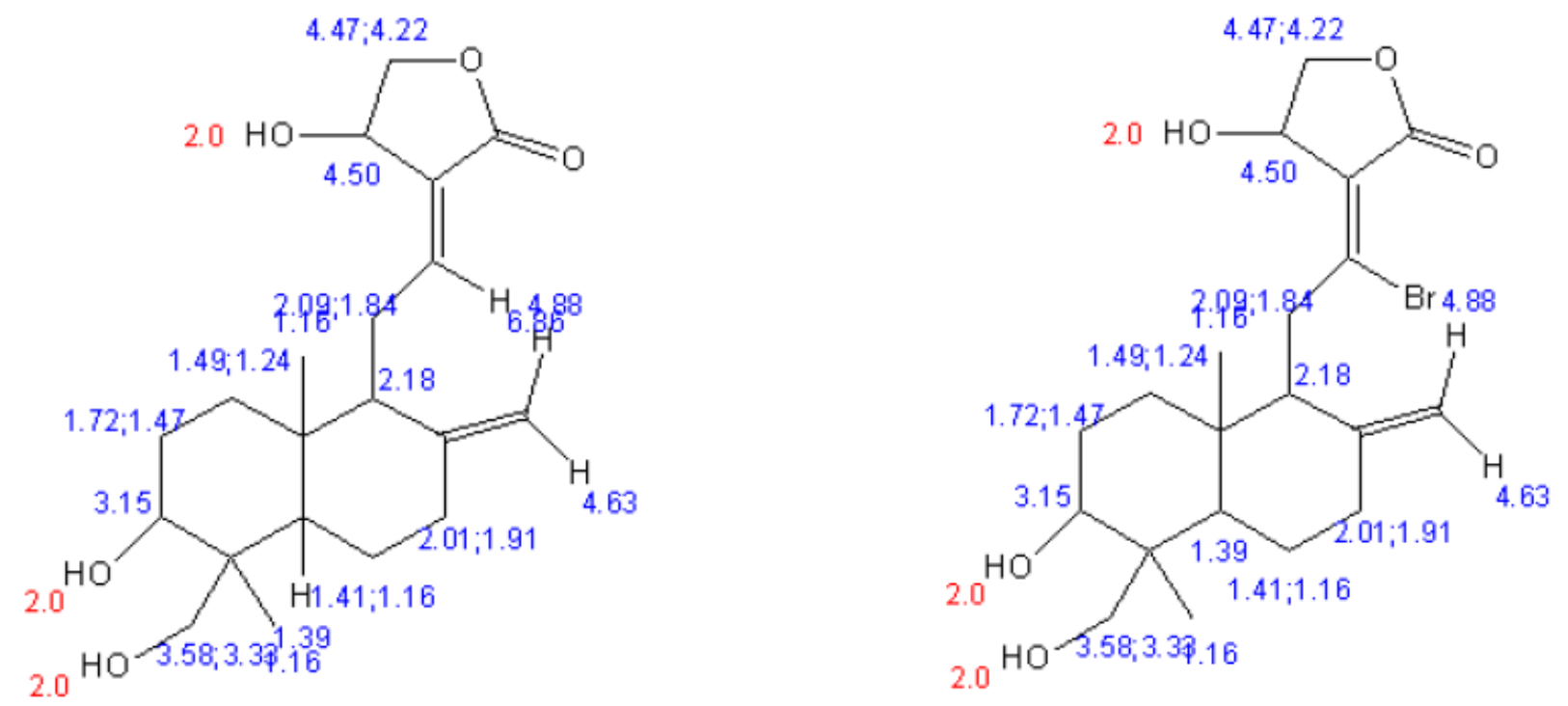

Figure 6. ${ }^{1} \mathrm{H}-\mathrm{NMR}$ chemical shift estimation of andrographolide (left) and bromo-andrographolide (right) 